\title{
Medicaid Work Requirements: Who Will the New State Policies Impact?
}

\author{
Jessica Greene, Ph.D. \\ Marxe School of Public and International Affairs, Baruch College, City University of New York, New York, NY, USA.
}

J Gen Intern Med 34(4):532-4

DOI: $10.1007 / \mathrm{s} 11606-018-4764-4$

(c) Society of General Internal Medicine 2019

$\mathrm{E}$ arly in 2018, the Trump administration approved four states (AR, IN, KY, and NH) to implement Medicaid work requirements, a controversial policy requiring nondisabled adults to spend at least 20 hours a week working, volunteering, attending school or job training, or searching for employment in order to receive Medicaid. In October, Wisconsin's Medicaid work requirement was also approved, and there are 10 states with pending applications. While the Centers for Medicare and Medicaid Services' Administrator described work requirements as "a policy that makes Medicaid a path out of poverty," 1 the Obama administration rejected the policy because reducing health care access was viewed as inconsistent with the objectives of Medicaid. ${ }^{2}$ In June, Arkansas was the first state to begin implementing Medicaid work requirements. The other four states are scheduled to begin implementation in 2019, though Kentucky may face a second legal challenge (the first halted implementation shortly before the scheduled July 2018 start) and Wisconsin's newly elected Democratic governor may not implement the policy. ${ }^{3}$

Recent analyses have found many Medicaid recipients already work. $\mathrm{Ku}$ and Brantley found that $87 \%$ of adults covered by Medicaid's expansion either work, are in school, or are seeking work. ${ }^{4}$ Another analysis found that $28 \%$ of Kentucky Medicaid recipients did not work and were not exempt from the requirement, but three quarters of them reported serious health issues or other limiting circumstances. ${ }^{5}$

This study uses a national survey of non-working adults to identify Medicaid recipients who would be potentially subject to the initial four approved states' work requirements, which differ in inclusion and exemption criteria, and to examine their demographic characteristics and attitudes towards working.

\section{METHODS}

We analyzed a November 2014 national telephone survey of non-working adults aged 25-54 conducted by the Kaiser Family Foundation, New York Times, and CBS News $(n=1002){ }^{6}$ Based upon each state's work requirement eligibility rules, we

Published online January 8, 2019 identified the percentage of Medicaid respondents who were likely exempt, possibly exempt, and not likely exempt.

The following groups were considered likely exempt: recipients of Supplemental Security Income or Social Security Disability Insurance, full-time students, parents or guardians of children under age $6(\mathrm{NH}), 7$ (IN), or 18 (AR, KY) living in the household. In Kentucky and Indiana, only one parent can be exempt, and we assumed the mother would use the exemption.

Also exempt are people who are medically frail, which is determined by each state. We considered those in fair or poor physical or mental health, and those with a disability as possibly exempt, as were part-time students. The rest were considered not likely exempt. The survey, notably, was not able to identify those meeting other exemption criteria like pregnancy or caring for a disabled adult.

\section{RESULTS}

Under the four states' policies, two-thirds or more of nonworking Medicaid recipients would likely be exempt from work requirements (Table 1). Based on the states' policies, as many as 14-27\% more could possibly be exempt. In Arkansas and Kentucky, only $3 \%$ and $4 \%$ of non-working Medicaid recipients were respectively not likely exempt, and in Indiana and New Hampshire, the rates were $7 \%$ and $8 \%$.

Of those potentially subject to the work requirement (possibly exempt and not likely exempt), more than three quarters in each state reported being in fair or poor health or having a disability (Table 2). Approximately $90 \%$ had a high school degree or less, and over a quarter had a criminal history. The majority, however, reported currently wanting a job and that it was very or somewhat likely that they would be working within a year.

\section{DISCUSSION}

The vast majority of non-working Medicaid recipients will be exempt from Medicaid work requirements because of disabilities and parenting responsibilities. If states are generous in granting medically frail exemptions, only a small percentage (approximately 3\%-8\%) of non-working Medicaid recipients will be subject to the policies, 
Table 1 Percentage of Non-working Adults with Medicaid Who Would Be Exempt, Possibly Exempt, or Not Likely Exempt from Medicaid Work Requirement Programs in Arkansas, Indiana, Kentucky, and New Hampshire

\begin{tabular}{|c|c|c|c|c|}
\hline & \multicolumn{4}{|c|}{ State Medicaid work requirement policies } \\
\hline & Arkansas $(n=161)$ & Indiana $(n=231)$ & Kentucky $(n=231)$ & New Hampshire $(n=231)$ \\
\hline Likely exempt* & $137(83 \%)$ & $165(66 \%)$ & $188(78 \%)$ & $168(67 \%)$ \\
\hline $\begin{array}{l}\text { Supplemental Security Income (SSI) or Social } \\
\text { Security Disability Insurance (SSDI) }\end{array}$ & $84(43 \%)$ & $136(48 \%)$ & $136(48 \%)$ & $136(48 \%)$ \\
\hline $\begin{array}{l}\text { Parent or guardian of child under the age of } \\
6(\mathrm{NH}) / 18(\mathrm{AR}) \text { living in the household }\end{array}$ & $71(49 \%)$ & - & - & $30(15 \%)$ \\
\hline $\begin{array}{l}\text { Single parent or guardian of child under the age } \\
\text { of } 7 \text { (IN)/18 (KY) living in household }\end{array}$ & - & $12(7 \%)$ & $33(17 \%)$ & - \\
\hline $\begin{array}{l}\text { Woman parent or guardian of child under the } \\
\text { age of } 7 \text { (IN) } / 18(\mathrm{KY}) \text { living in household } \\
\text { with spouse/partner }\end{array}$ & - & $12(6 \%)$ & $29(16 \%)$ & - \\
\hline Full-time student & $19(15 \%)$ & $19(12 \%)$ & $19(12 \%)$ & $19(12 \%)$ \\
\hline Possibly exempt* & $19(14 \%)$ & $52(27 \%)$ & $34(18 \%)$ & $48(25 \%)$ \\
\hline Fair/poor physical health & $15(10 \%)$ & $42(22 \%)$ & $28(14 \%)$ & $39(21 \%)$ \\
\hline Fair/poor mental health & $12(7 \%)$ & $31(15 \%)$ & $19(6 \%)$ & $29(14 \%)$ \\
\hline Disability & $12(8 \%)$ & $32(16 \%)$ & $24(12 \%)$ & $30(15 \%)$ \\
\hline Part-time student & $1(2 \%)$ & $3(2 \%)$ & $1(1 \%)$ & $1(1 \%)$ \\
\hline Not likely exempt* & $5(3 \%)$ & $14(7 \%)$ & $9(4 \%)$ & $15(8 \%)$ \\
\hline
\end{tabular}

All analyses were weighted to adjust for survey sampling. While this survey data does not include people younger than 25 , the work requirement policies in all four states include 19-24-year-olds. In KY and NH, the upper age for inclusion is 64, and in IN it is 59, though this survey data includes only people up to age 54. AR does not include adults over 49 years old in the work requirement, so survey respondents aged 50 and older are excluded from analysis

*The percent in the likely exempt category includes all those who meet one or more criteria below for being likely exempt. The possibly exempt percentage is also meeting one or more of the possible exempt criteria. The percent in the not likely exempt category includes those neither included in the likely exempt nor possibly exempt categories.

${ }^{7} I N$ and NH exclude those who are the parent or guardian of children under age 7 and 6 respectively from the work requirement, so based on analysis from the American Community Survey that indicated 40\% of those with children under the age of 18 had children under aged 6 at home, we randomly selected $40 \%$ of those with children under 18 at home

${ }^{7} I N$ and $K Y$ only allow one parent with a child at home to be exempt from the work requirement. We assumed that it would be the female in a couple who would take the exemption, so we include only those single parent, and woman parent of child with partner/spouse in the household. For AR and NH, we included all parents or guardians of children in the household of the appropriate age

Table 2 Demographic Characteristics and Attitudes Towards Employment Among Non-working Medicaid Recipients Potentially Subject to Medicaid Work Requirements Under Each State's Rules

\begin{tabular}{|c|c|c|c|c|}
\hline & \multicolumn{4}{|c|}{ Non-working Medicaid recipients } \\
\hline & \multicolumn{4}{|c|}{ Potentially subject to work requirement by state policies } \\
\hline & \multirow{2}{*}{$\frac{\overline{\text { Arkansas }}}{(n=24)}$} & \multirow{2}{*}{$\begin{array}{l}\text { Indiana } \\
(n=66)\end{array}$} & \multirow{2}{*}{$\frac{\text { Kentucky }}{(n=43)}$} & \multirow{2}{*}{$\begin{array}{l}\text { New Hampshire } \\
(n=63)\end{array}$} \\
\hline & & & & \\
\hline \multicolumn{5}{|l|}{ Demographic characteristics } \\
\hline Female & $16(73 \%)$ & $44(70 \%)$ & $23(57 \%)$ & $43(71 \%)$ \\
\hline \multicolumn{5}{|l|}{ Age (in years) } \\
\hline$<35$ & $11(48 \%)$ & $24(41 \%)$ & $12(32 \%)$ & $23(42 \%)$ \\
\hline $35-44$ & $4(18 \%)$ & $11(18 \%)$ & $5(14 \%)$ & $10(18 \%)$ \\
\hline $45-49$ & $9(34 \%)$ & $15(24 \%)$ & $10(28 \%)$ & $14(23 \%)$ \\
\hline $50-54$ & - & $16(17 \%)$ & $16(26 \%)$ & $16(18 \%)$ \\
\hline \multicolumn{5}{|l|}{ Education } \\
\hline Less than high school & $8(43 \%)$ & $15(32 \%)$ & $11(39 \%)$ & $14(31 \%)$ \\
\hline High school & $14(50 \%)$ & $42(57 \%)$ & $26(53 \%)$ & $42(61 \%)$ \\
\hline More than high school & $2(7 \%)$ & $9(11 \%)$ & $6(9 \%)$ & $7(8 \%)$ \\
\hline \multicolumn{5}{|l|}{ Race/ethnicity } \\
\hline White & $13(52 \%)$ & $35(47 \%)$ & $24(49 \%)$ & $34(48 \%)$ \\
\hline Black & $6(23 \%)$ & $13(20 \%)$ & $9(19 \%)$ & $13(21 \%)$ \\
\hline Latino & $4(22 \%)$ & $13(25 \%)$ & $7(24 \%)$ & $11(23 \%)$ \\
\hline Other & $1(3 \%)$ & $5(7 \%)$ & $3(8 \%)$ & $5(8 \%)$ \\
\hline Parent or guardian of child under 18 years of age at home & $0(0 \%)$ & $27(45 \%)$ & $4(13 \%)$ & $24(42 \%)$ \\
\hline Health issue (fair/poor physical or mental health, or disability) & $19(80 \%)$ & $51(77 \%)$ & $34(80 \%)$ & $48(77 \%)$ \\
\hline Criminal history & $8(25 \%)$ & $20(28 \%)$ & $12(25 \%)$ & $19(29 \%)$ \\
\hline \multicolumn{5}{|l|}{ Employment attitudes \& behaviors } \\
\hline \multicolumn{5}{|l|}{ Currently wants a job } \\
\hline Yes & $16(55 \%)$ & $49(72 \%)$ & $30(64 \%)$ & $47(72 \%)$ \\
\hline Yes, but unable to work & $1(9 \%)$ & $2(5 \%)$ & $2(8 \%)$ & $2(5 \%)$ \\
\hline No/do not know & $7(36 \%)$ & $15(23 \%)$ & $11(28 \%)$ & $14(23 \%)$ \\
\hline \multicolumn{5}{|l|}{ Contacted someone about job } \\
\hline In last month & $8(22 \%)$ & $22(32 \%)$ & $12(22 \%)$ & $19(28 \%)$ \\
\hline $2-5$ months ago & $4(20 \%)$ & $12(20 \%)$ & $6(17 \%)$ & $12(21 \%)$ \\
\hline Longer/never & $12(58 \%)$ & $32(48 \%)$ & $25(61 \%)$ & $32(51 \%)$ \\
\hline Likely to be working in a year & & & & \\
\hline
\end{tabular}


Table 2. (continued)

\begin{tabular}{|c|c|c|c|c|}
\hline & \multicolumn{4}{|c|}{ Non-working Medicaid recipients } \\
\hline & \multicolumn{4}{|c|}{ Potentially subject to work requirement by state policies } \\
\hline & \multirow{2}{*}{$\frac{\text { Arkansas }}{(n=24)}$} & \multirow{2}{*}{$\frac{\text { Indiana }}{(n=66)}$} & \multirow{2}{*}{$\frac{\text { Kentucky }}{(n=43)}$} & \multirow{2}{*}{$\frac{\text { New Hampshire }}{(n=63)}$} \\
\hline & & & & \\
\hline Very likely & $9(31 \%)$ & $27(41 \%)$ & $14(27 \%)$ & $27(43 \%)$ \\
\hline Somewhat likely & $6(31 \%)$ & $16(27 \%)$ & $10(29 \%)$ & $12(22 \%)$ \\
\hline Not too likely/not likely at all & $9(38 \%)$ & $23(32 \%)$ & $19(44 \%)$ & $24(35 \%)$ \\
\hline \multicolumn{5}{|l|}{ Major reasons not employed } \\
\hline Health problems or disability & $13(52 \%)$ & $37(54 \%)$ & $24(55 \%)$ & $35(54 \%)$ \\
\hline Family responsibilities & $6(14 \%)$ & $24(35 \%)$ & $10(18 \%)$ & $23(35 \%)$ \\
\hline Lack of education or skills & $5(15 \%)$ & $19(28 \%)$ & $10(22 \%)$ & $15(21 \%)$ \\
\hline Lack of good jobs available & $13(46 \%)$ & $34(49 \%)$ & $18(36 \%)$ & $31(47 \%)$ \\
\hline
\end{tabular}

All analyses were weighted to adjust for survey sampling. Percentages may not add up to $100 \%$ due to rounding. Potentially subject to the work requirement includes those who are "not likely exempt" and "possibly exempt"

resulting in little employment gain. If states are not generous with exemptions, as many as $17 \%-34 \%$ will be subject to work requirements. While there may be greater employment gains under this scenario, transitioning many in this group into the workforce will be very challenging and those unable to meet the requirements will lose their health coverage. Most report wanting jobs; however, the vast majority report serious health issues, few have more than a high school education, and in Indiana and New Hampshire, over a third have a child aged 6-17 at home.

Acknowledgements: I would like to thank the Kaiser Family Foundation for sharing their survey data.

Corresponding Author: Jessica Greene, Ph.D.; Marxe School of Public and International Affairs, Baruch College, City University of New York, New York, NY, USA (e-mail: Jessica.greene@baruch.cuny. edu).

\section{Compliance with Ethical Standards:}

Conflict of Interest: The author declares that she has no conflicts of interest.

Publisher's Note: Springer Nature remains neutral with regard to jurisdictional claims in published maps and institutional affiliations.

\section{REFERENCES}

1. Verma S. Making Medicaid a Pathway Out of Poverty. Washington Post. February 2, 2018. Available at: https://www.washingtonpost.com/opinions / making-medicaid-a-pathway-out-of-poverty/2018/02/04/ 4570736a-0857-11e8-94e8-e8b8600ade23_story.html?utm_term=. b849d1f35fb8. Accessed 4 September 2018.

2. Slavitt AM. Department of Health and Human Services Letter. September 30, 2016. Available at: https://www.medicaid.gov/Medicaid-CHIP-Program-Information/By-Topics/Waivers/1115/downloads/az/Health-CareCost-Containment-System/az-hccc-demo-ext-09302016.pdf. Accessed 4 September 2018.

3. Owermohle S. Trump Admin Reapproves Kentucky's Medicaid Work Requirement Waivers. Politico Pusle. 11/21/2018. https://www.politico. com/newsletters/politico-pulse/2018/11/21/trump-admin-reapproveskentuckys-medicaid-work-requirement-waivers-425647. Accessed 16 December 2018.

4. Ku L, Brantley E. Myths about the Medicaid expansion and the "AbleBodied.”. Health Affairs Blog. March 6, 2017. Available at: https://www. healthaffairs.org/do/10.1377/hblog20170306.059021/full/. Accessed 4 September 2018.

5. Gangopadgyaya A, Kenney G. Who Could Be Affected by Kentucky's Medicaid Work Requirements, and What Do We Know about Them? Washington, DC; 2/2018. Available at: https://www.urban.org/sites/ default/files/publication/96576/2018.02.15_ky_medicaid_numbers_finalized_0.pdf. Accessed September 4, 2018.

6. Hamel L, Firth J, Brodie M. Kaiser Family Foundation/New York Times/CBS News Non-Employed Poll. Washington, DC; 12/11/2014. Available at: https://www.kff.org/other/poll-finding/kaiser-familyfoundationnew-york-timescbs-news-non-employed-poll/. Accessed 4 September 2018. 